\title{
The Skin of the Male African Catfish, Clarias gariepinus: A Source of Steroid Glucuronides
}

\author{
S. A. Ali, ${ }^{*}$ W. G. E. J. Schoonen, J. G. D. Lambert, $\dagger$ R. VAN Den Hurk, AND \\ P. G. W. J. VAN OORDT
}

Department of Experimental Zoology, Research Group Comparative Endocrinology, University of Utrecht, Padualaan 8, $3584 \mathrm{CH}$ Utrecht, The Netherlands, and ${ }^{*}$ Central Marine Fisheries Research Institute. Prawn Culture Lab, Narakal 682505, India

Accepted January 24, 1987

\begin{abstract}
Steroid metabolism in the skin of mature male African catfish, Clarias gariepinus, reared in the laboratory, was studied in vitro by tissue incubations with $\left[{ }^{3} \mathrm{H}\right]$ pregnenolone, $\left[{ }^{3} \mathrm{H}\right] \mathrm{de}-$ hydroepiandrosterone, $\left[{ }^{3} \mathrm{H}\right] 17 \alpha$-hydroxyprogesterone, $\left[{ }^{3} \mathrm{H}\right]$ androstenedione, $\left[{ }^{14} \mathrm{C}\right] 11 \beta$-hydroxyandrostenedione, and $\left[{ }^{3} \mathrm{H}\right]$ testosterone as precursors. While pregnenolone was not converted to any other steroid, dehydroepiandrosterone was transformed mainly to 5-androstene-3 $3,17 \beta$-diol. The products of $17 \alpha$-hydroxyprogesterone incubations were $5 \beta$-preg-

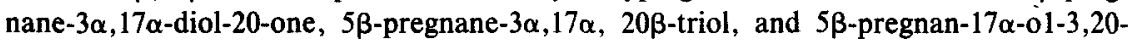
dione. The major steroids of androstenedione incubations were etiocholanolone, testosterone, and androsterone. Testosterone was converted mainly to etiocholanolone and androstenedione, and only small quantities of $11 \beta$-hydroxytestosterone, 11-ketotestosterone, and 11-ketoandrostenedione were the metabolites found in 11 $\beta$-hydroxyandrostenedione incubation. These results demonstrated the presence of the enzymes $5 \alpha$ - and $5 \beta$-reductases and $3 \alpha-, 11 \beta-, 17 \beta-$, and $20 \beta$-hydroxysteroid dehydrogenases in the skin. From enzymehistochemical results it appeared that the steroid conversions take place in the epithelial cells. Moreover, the presence of UDP-glucose dehydrogenase, an enzyme involved in the synthesis of glucuronic acid, in these cells indicates the possibility of steroid glucuronide formation. Indeed significant amounts of water-soluble steroid conjugates, particularly $5 \beta$-dihydrotestosterone- and testosterone-glucuronide, were found in the incubations with androstenedione and testosterone, indicating the presence of the UDP-glucuronosyl transferase in the catfish skin. In the light of these results, a role of the skin of African catfish in the production of semiochemicals having pheromonal properties is discussed. 1987 Academic Press, Inc.
\end{abstract}

The skin, forming the boundary of a multicellular organism with its outside world, assists in communication with other organisms. To that end it may excrete substances that function as pheromones (Pfeiffer, 1982). This is, e.g., the case in Ictalurus species (Todd et al., 1967; Richards, 1974). In other fish species, e.g., Gobius jozo (Colombo et al., 1982), zebrafish, Brachydanio rerio (Van den Hurk and Lambert, 1983; Lambert et al., 1986; Van den Hurk et al., 1987), and African catfish Clarias gariepinus (Lambert et al., 1986; Resink et al., 1987), pheromones of gonadal origin can induce brecding bchavior

$\dagger$ To whom correspondence should be addressed. and spawning. In the goby and the zebrafish these pheromones are steroid glucuronides. In the African catfish steroid glucuronides are being produced by the male seminal vesicles and the female ovaries (Schoonen and Lambert, 1986b; Schoonen et al., 1987a,c), and preliminary investigations by Resink and Van den Hurk point to these water-soluble steroids as sex pheromones in this species.

The gonads, however, may not be the only organ that produces and excretes pheromonal steroid glucuronides. Indeed, in vitro studies by Hay et al. (1976) and Soivio et al. (1982) indicate the presence of the enzymes $3 \alpha$-hydroxysteroid dehydro-

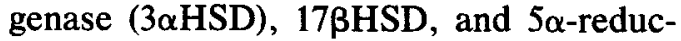
15 
tase in the skin of the rainbow trout Salmo gairdneri and the brown trout, Salmo trutta lacustris, respectivcly, and water-soluble steroid conjugates were found in skin incubations of brown trout. This points to the skin as a possible source of pheromonal steroid conjugates. In evaluating such an hypothesis for the African catfish, the first thing to do is study steroid metabolism in the skin. To that end, skin fragments of $C$. gariepinus are studied biochemically by incubations in vitro using six different radiolabeled steroid precursors, and enzymehistochemically by demonstrating enzyme activities involved in the synthesis of steroids and glucuronic acid.

\section{MATERIAL AND METHODS}

Animals. African catfish, C. gariepinus, were reared from eggs to maturity in the laboratory. The breeding techniques and hatchery conditions have been reported by De Leeuw et al. (1985). Pieces ( $5 \times$ $7 \mathrm{~cm}$ ) of skin taken from the lateral side of the fish from dorsal to ventral were obtained from adult male fish (weight $500 \mathrm{~g}$ ), cleaned from adipose tissue, and prepared for in vitro incubations to study the bioconversions of steroids and for histological and enzymehistochemical studies.

Histology and enzymehistochemistry. Enzymehistochemical studies were carried out on $10-\mu \mathrm{m}$-thick transversal sections of tissues that were immediately frozen with $\mathrm{CO}_{2}$ after killing the fish, and cut with a cryostat microtome (Minotome TH, Damon/IEC Division) at $-25^{\circ}$. The enzymes $3 \beta$ - and $3 \alpha$-hydroxysteroid dehydrogenase were demonstrated according to the method of Van den Hurk (1973) with epiandrosterone and etiocholanolone, respectively, as substrates. The incubation temperature was $30^{\circ}$ and the incubation time $3 \mathrm{hr}$. 11ß-Hydroxysteroid dehydrogenase $(11 \beta-H S D)$ was demonstrated with the same method, using $11 \beta$-hydroxyandrostenedione as substrate. $17 \beta$-Hydroxysteroid dehydrogenase $(17 \beta$ HSD) was demonstrated according to the method of Kellog and Glenner (1960) with testosterone as sub. strate in a medium ( $\mathrm{pH} 9.2$ ) containing $0.1 \mathrm{mg} / \mathrm{ml}$ polyvinylpyrrolidone $\left(M_{r}, 125,000\right)$ instead of crystalline bovine albumin. Demonstration of UDP-glucose dehydrogenase (UDPGD) was carried out according to the method of Van den Hurk et al. (1987). Sections were also incubated in solutions lacking substrate or co-factor to control the specificity of the reaction. In addition, uridine- $5^{\prime}$-diphosphoxylose $(1 \mathrm{mM})$ was used as an inhibitor of the UDPGD reaction.

Alternate frozen sections and 7 - $\mu \mathrm{m}$-thick paraffin sections of tissues fixed in Bouin-Hollande were stained with Mayer's hemalum-eosin (Burck, 1981) for more detailed morphological information.

Chemicals. $\left[7^{3} \mathrm{H}\right]$ Pregnenolone $(9.4 \mathrm{Ci} / \mathrm{mmol})$, $\left[7-{ }^{3} \mathrm{H}\right] 17 \alpha$-hydroxyprogesterone $(10.7 \mathrm{Ci} / \mathrm{mmol})$, $\left[7 .{ }^{3} \mathrm{H}\right]$ androstenedione $(9.2 \mathrm{Ci} / \mathrm{mmol}),\left[7 .{ }^{3} \mathrm{H}\right]$ testosterone $(12.4 \mathrm{Ci} / \mathrm{mmol})$, and $\left[7 .{ }^{3} \mathrm{H}\right]$ dehydroepiandrosterone $(14.5 \mathrm{Ci} / \mathrm{mmol})$ were obtained from Radio Chemical Centre, Amersham (U.K.). $\left[4 \cdot{ }^{14} \mathrm{C}\right] 11 \beta$-hydroxyandrostenedione $(55.1 \mathrm{mCi} / \mathrm{mmol})$ was prepared from $\left[4-{ }^{14} \mathrm{C}\right]$ cortisol with sodium bismuthate (Bush, 1961). The purity of these chemicals was checked by thin-layer chromatography (TLC) before use. Leibovitz L-15 medium was from Serva and Hepes was from Boehringer. The substrates used in the enzymehistochemical studies were from Merck. All chemicals used in the experiments were of analytical grade.

Chromatography. Thin-layer ehromatography was carried out on precoated plates with Silica F254 (Merck A.G.) in saturated tanks with the following systems: I, toluene-cyclohexane (1:1); II, benzeneethyl acetate (3:1); III, chloroform-ethanol (95:5); IV, diisopropylether-chloroform-hexane $(7: 2: 1)$; V, ethylacetate-hexane-acetic acid (75:20:5). Carrier and reference steroids were identified by uv absorption (3keto- $\Delta^{4}$ - steroids) or by spraying with primuline according to Wright (1971).

The relative $R_{f}$ values $\left[R_{s}(T)\right.$ are expressed against testosterone. Microchemical reactions, recrystallizations, and measurement of radioactive samples were carried out according to Schoonen and Lambert (1986a). Radioactive areas on TLC plates were located and quantified by means of a Berthold thin-layer chromatogram linear scanner (LB 2842). Only the radioactive areas having more than $1 \%$ of the total activity were identified.

Incubation procedure. The incubations were carried out with $0.5 \mathrm{~g}$ of skin cut into small pieces of $\pm 1 \mathrm{~mm}^{2}$ in $2 \mathrm{ml}$ Leibovitz medium fortified with $15 \mathrm{mM}$ Hepes (pH 7.4) containing $2.1 \mu \mathrm{Ci}$ of the radiolabeled precursor dissolved in $100 \mu \mathrm{l}$ of propyleneglycol. No cofactors were added. As the water temperature in which the animals lived was $26^{\circ}$, the incubations were carried out at this temperature under continuous shaking in an air atmosphere for $3 \mathrm{hr}$. The enzyme reactions were terminated by addition of $10 \mathrm{ml}$ ethanol. All the incubations were carried out in duplicate using two fish.

Extraction. Before extraction, $25 \mu \mathrm{g}$ of each of the following carrier steroids were added based on the results of steroid metabolism in testes and seminal vesicles (Schoonen and Lambert, 1986a,b, Schoonen et al., 1987a,b). To incubations with pregnenolone and $17 \alpha$-hydroxyprogesterone were added pregnenolone, $17 \alpha$-hydroxypregnenolone, progesterone, $17 \alpha$-hydroxyprogesterone, androstenedione, testosterone, $11 \beta$-hydroxyandrostenedione, $11 \beta$-hydroxytestosterone, and 11 -ketotestosterone. $5 \beta$-Pregnane-3 $\alpha, 17 \alpha-$ 
diol-20-one was added only to incubations with $17 \alpha-$ hydroxyprogesterone. To all the other incubations were added androstenedione, testosterone, $11 \beta$ hydroxyandrostenedione, 11 -hydroxytestosterone, 11-ketotestosterone, $5 \beta$-androstan-3 $\alpha$-ol-17-one (etiocholanolone), $5 \beta$-androstan-3 $\beta$-ol-17-one (epietiocholanolone), $5 \beta$-androstane-3 $\alpha, 17 \beta$-diol, $5 \alpha$-androstane$3 \alpha, 17 \beta$-diol, $5 \beta$-androstane- $3 \beta, 17 \beta$-diol, and $5 \beta$-dihydrotestosterone. In addition, dehydroepiandrosterone was added only to the incubations with $\left[{ }^{3} \mathrm{H}\right]$ dehydroepiandrosterone.

The products from the incubations were extracted by ethanol $(3 \times 10 \mathrm{ml})$. The ethanol-medium mixture was evaporated to dryness under nitrogen and the residue was redissolved in $2 \mathrm{ml}$ of distilled water. Dichloromethane was then added $(3 \times 10 \mathrm{ml})$ to extract the free steroids from the water. The combined extracts of the organic fraction were evaporated and the residue was dissolved in a few drops of dichloromethane-methanol $(9: 1)$. This final solution in total was subjected to TLC in system I to remove the nonpolar compounds from steroids. In this system the steroids remain on the baseline; therefore it was possible, after drying, to use the same plate for the first separation of steroids in system II.

The remaining water fractions, containing $10 \%$ or more of the original aclivity, were treated with $\beta$-glucuronidase of Escherichia coli (Schoonen and Lambert, 1986b) and free steroids were extracted with dichloromethane $(3 \times 10 \mathrm{ml})$ and separated by TLC as in the case of the original organic fraction.

\section{RESULTS}

\section{Histology and Enzymehistochemistry}

The skin of $C$. gariepinus has no scales and is composed of two distinct layers: the epidermis and, beneath this, the dermis (Fig. 1A). The epidermis is a stratified epithelium with numerous mucous glands and so-called club cells with two central nuclei. The dermis is a composite layer a.o. including connective tissue, muscle fibers, and capillary blood vessels (Fig. 1A). The deeper main portion of the dermis, the stratum compactum, consists of dense connective tissue with collagenous fibers running more or less parallel to the surface. Occasionally, bundles are oriented perpendicular. The outer surface of the dermis, the stratum vasculare, is in contact with the epithelium and consists of looser connective tissue with much thinner collage- nous bundles. A network of fibroblasts is distributed between the collagenous bundles. They are more abundant in the outer layer than in the deeper layer of the dermis. Beneath the dermis is found the hypodermis, a narrow layer of loose connective tissue and subcutaneous adipose tissue.

$3 \beta$-HSD could not be demonstrated in the skin, but weak $3 \alpha-, 11 \beta-$, and 173-HSD activity was found in the epithelial cells (Fig. 1B). In these cells UDPGD activity was moderate (Fig. 1C). In addition, a moderate to strong UDPGD reaction was found in the fibroblasts of the dermis. Sections of skin that were incubated in substrate-free or co-factor-free media remained unstained. UDP-xylose completely inhibited the UDPGD reaction.

\section{Incubation with $\left[{ }^{3} \mathrm{H}\right]$ Pregnenolone}

After chromatography in system II and scanning, only one radioactive area was observed in this incubation. After TLC in system III, acetylation, and recrystallization, it was confirmed that the single area was the precursor itself (Table 1), indicating that pregnenolone was not metabolized to any other steroid.

\section{Incubation with}

\section{$\left[{ }^{3} \mathrm{H}\right]$ Dehydroepiandrosterone}

The distributions of radioactivity between the organic and the water fractions were 78 an $22 \%$, respectively. After separation in system II the organic fraction gave two areas. These two areas, after TLC in system III, corresponded to the carriers 5androstene- $3 \beta, 17 \beta$-diol and dehydroepiandrosterone. After acetylation and recrystallization these radioactive compounds were proven to be 5 -androstene- $3 \beta, 17 \beta$-diol and the precursor dehydroepiandrosterone (Table 1).

In the water fraction after glucuronidase treatment and extraction, only one radioactive area was found after TLC and scan- 

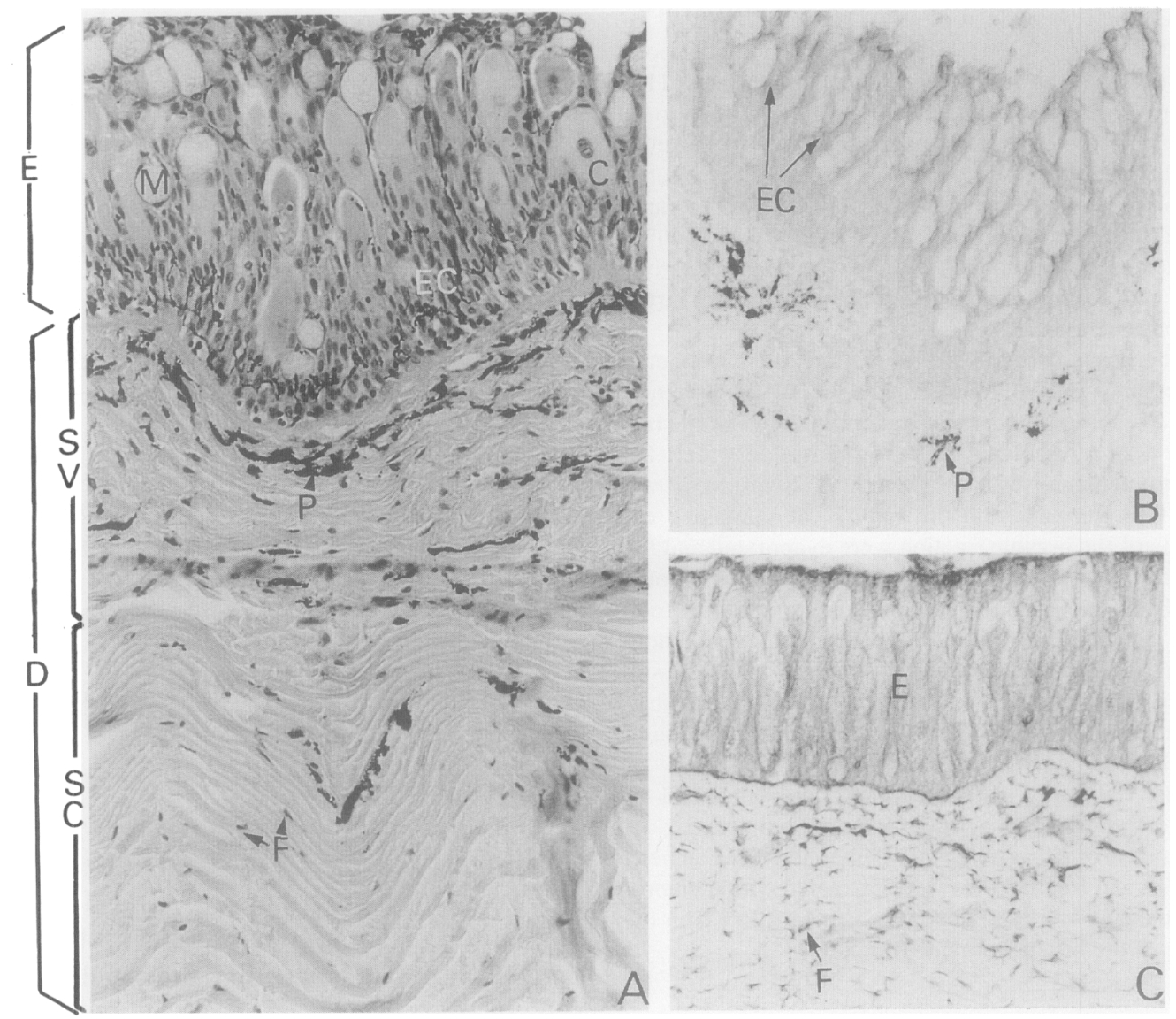

Fig. 1. Histological sections of the skin of Clarias gariepinus. (A) General structure. Hemalumeosin, $\times 230$. (B) 17ß-Hydroxysteroid dehydrogenase, with a weak enzyme activity in epithelial cells. $\times 145$. (C) UDP-glucose dehydrogenase. Enzyme activity is demonstrated in the epidermis and fibroblasts. $\times 145$. C, club cells; D, dermis; E, epidermis; EC, epithelial cells; F, fibroblasts; M, mucous gland; P, pigment; SC, stratum compactum; SV. stratum vasculare.

ning. The substance was confirmed as 5 androstene- $3 \beta, 17 \beta$-diol after TLC in system III, derivatization, and recrystallization (Table 1).

\section{Incubation with}

$\left[{ }^{3} \mathrm{H}\right] 17 \alpha$-Hydroxyprogesterone

Of the total radioactivity, $90 \%$ was found in the organic fraction. After separation by TLC in system II, four radioactive areas were found in this fraction (Fig. 2) with the following $R_{s}(\mathrm{~T})$ values: area $\mathrm{A}, 0.09$ to 0.22 ; area $B, 0.43$ to 0.56 ; area $C, 1.10$ to 1.22; and area $D, 1.31$ to 1.44 . In area $A$, after rechromatography in systems III and
IV, two radioactive areas were observed, one corresponding to $5 \beta$-pregnane-3 3 ,$17 \alpha, 20 \alpha$-triol and the other to $5 \beta$-pregnane$3 \alpha, 17 \alpha, 20 \beta$-triol. The areas B, C, and D were eluted and rechromatographed separately in system III and, after derivatization and recrystallization, were found to be $5 \beta$-pregnane-3 $\alpha, 17 \alpha$-diol-20-one, $17 \alpha$-hydroxyprogesterone, and 5 $\beta$-pregnan-17 $\alpha$ ol-3,20-dione, respectively (Table 1).

The water fraction after treatment with $\beta$-glucuronidase, extraction, and chromatography in system II showed two areas with comparable $R_{s}(T)$ values as the areas $A$ and $B$ of the original organic fraction. These compounds were found to be $5 \beta$ - 


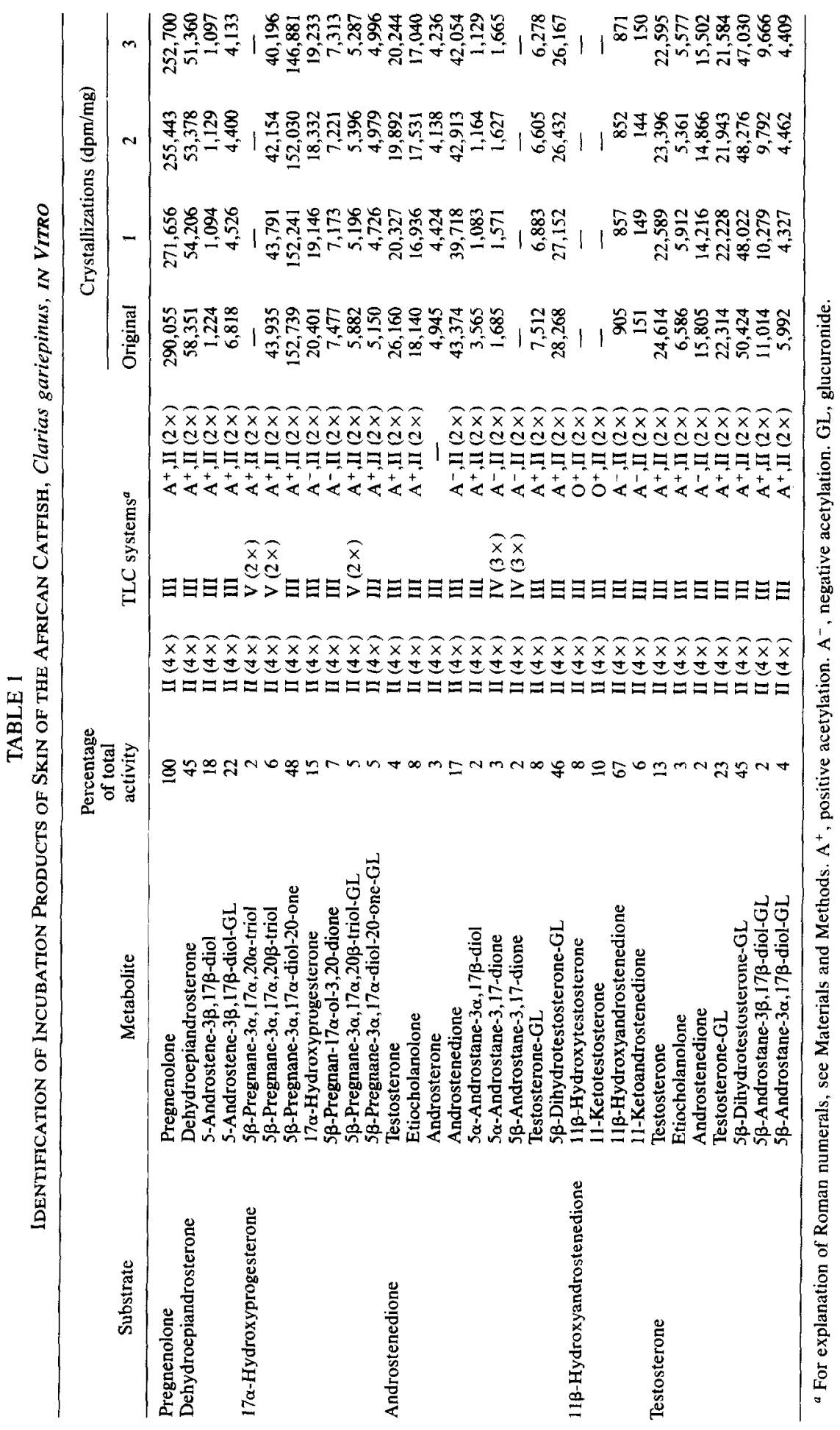




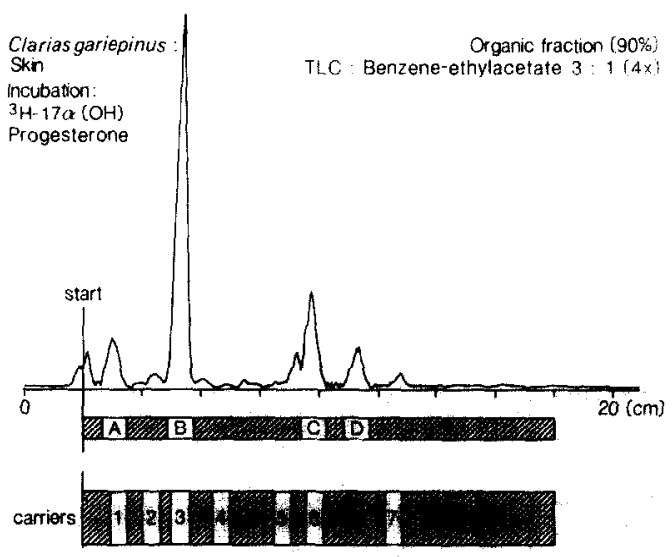

FIG. 2. Radiochromatogram of the organic fraction of skin incubation of Clarias gariepinus with $\left[{ }^{3} \mathrm{H}\right] 17 \alpha$ hydroxyprogesterone. Carriers: (1) 11ß-hydroxytestosterone, (2) 11-ketotestosterone, (3) 5 $\beta$-pregnane$3 \alpha, 17 \alpha$-diol-20-one, (4) $11 \beta$-hydroxyandrostenedione, (5) testosterone, (6) $17 \alpha$-hydroxyprogesterone, (7) androstenedione. Areas A-D were eluted.

pregnane-3 $3,17 \alpha, 20 \alpha$-triol and $5 \beta$-pregnane-3 $\alpha, 17 \alpha$-diol-20-one (Table 1).

\section{Incubation with $\left[{ }^{3} H\right]$ Androstenedione}

The incubation with $\left[{ }^{3} \mathrm{H}\right]$ androstenedione resulted in $46 \%$ of the radioactivity in the organic fraction and $54 \%$ in the water fraction. The organic fraction gave six radioactive areas after separation by TLC in system II with the following $R_{s}(\mathrm{~T})$ values: areas $\mathrm{A}, 0.93$ to 1.06 ; area $\mathrm{B}, 1.06$ to 1.21 ; area $\mathrm{C}, 1.28$ to 1.38 ; area $\mathrm{D}, 1.38$ to 1.49 ; area $\mathrm{E}, 1.49$ to 1.60 ; and area $\mathrm{F}, 1.78$ to 1.96 (Fig. 3A). After rechromatography in system III the following steroids could be identified: area $A$, testosterone and $5 \alpha$-androstane-3 $\alpha, 17 \beta$-diol; area $B$, etiocholanolone; area $\mathrm{D}$, androsterone; and area $\mathrm{E}$, androstenedione. The compound of area $\mathrm{C}$ could not be identified, while rechromatography of area F in systems III and IV resulted in two substances, $5 \alpha$-androstane3,17 -dione and $5 \beta$-androstane-3,17-dione (Table 1).

After treatment with $\beta$-glucuronidase and subsequent extraction with dichloromethane, $95 \%$ of the radioactivity of the water fraction passed to the organic phase,

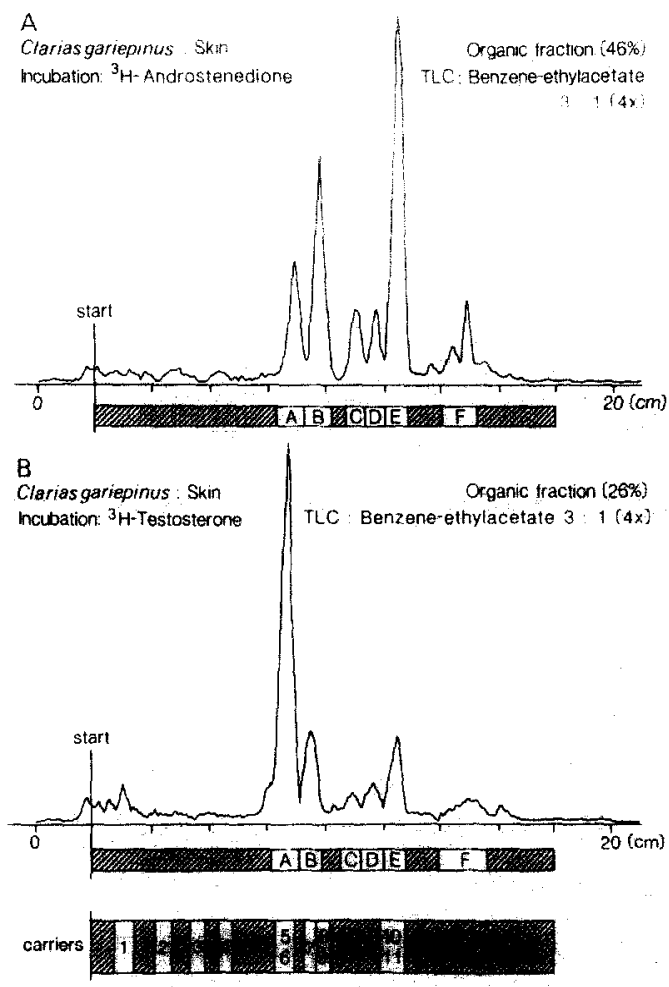

FIG. 3. Radiochromatograms of the organic fractions of skin incubations of Clarias gariepinus with $\left[{ }^{3} \mathrm{H}\right]$ androstenedione $(A)$ and $\left[{ }^{3} \mathrm{H}\right]$ testosterone $(B)$. Carriers: (1) 11ß-hydroxytestosterone, (2) 11-ketotestostcrone, (3) $5 \beta$-androstane-3 $\alpha, 17 \beta$-diol, (4) $11 \beta$-hydroxyandrostenedione, (5) $5 \alpha$-androstane-3 $\alpha$, 17 $\beta$-diol, (6) testosterone, (7) etiocholanolone, (8) $5 \beta$-andro-

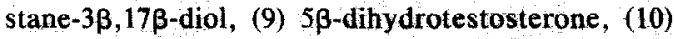
epietiocholanolone, (11) androstenedione. Areas A-F were eluted.

indicating that the steroid conjugates present were glucuronides. The free steroids, when subjected to TLC in system II, resulted in two radioactive areas. The first area $R_{s}(T), 0.9$ to 1.1 , after rechromatography in system III gave two compounds; one was $5 \alpha$-androstane- $3 \alpha, 17 \beta$-diol and the other testosterone. The second area $R_{s}(T)$, 1.1 to 1.3 , was found to be $5 \beta$-dihydrotestosterone (Table 1).

\section{Incubation with}

$\left[{ }^{14} \mathrm{C}\right] 11 \beta$-Hydroxyandrostenedione

In this incubation $95 \%$ of the radioactivity was recovered in the organic frac- 
tion. Following separation by TLC in system II, four radioactive areas were obtained. The compounds of these zones were rechromatographed in system III and were identified as $11 \beta$-hydroxytestosterone, 11-ketotestosterone, 11 $\beta$-hydroxyandrostenedione, and 11-ketoandrostenedione. The identity of the first two compounds was confirmed by oxidation and rechromatography of the product (11-ketoandrostenedione). The identity of the latter two compounds was confirmed by acetylation and recrystallization (Table 1).

\section{Incubation with $\left[{ }^{3} \mathrm{H}\right]$ Testosterone}

In the testosterone incubation, $26 \%$ of the total radioactivity was found in the dichloromethane phase and $74 \%$ was found in the water fraction. After separation by TLC in system II, the organic fraction gave five different radioactive areas (Fig. 3B). Area $A$ with $R_{s}(\mathrm{~T}) 0.91$ to 1.06 corresponded to the precursor testosterone, and area B with $R_{s}(\mathrm{~T}) 1.06$ to 1.18 was found to be etiocholanolone. Areas $\mathrm{C}$ and $\mathrm{D}$ with $R_{s}(T) 1.26$ to 1.37 and 1.37 to 1.49 , respectively, were not identified. After TLC in system III, area $\mathrm{E}$ with $R_{s}(\mathrm{~T}) 1.49$ to 1.60 corresponded to androstenedione (Table 1). Area $\mathrm{F}$ with $R_{s}(\mathrm{~T}) 1.76$ to 2.01 also was not identified.

From the fraction treated with $\beta$-glucuronidase, $95 \%$ of the radioactivity was recovered as free steroids. After separation by TLC in system II, three different radioactive areas were obtained. The first area was identified as $5 \beta$-androstane- $3 \alpha, 17 \beta$ diol. The second area, after rechromatography in system III, gave two peaks, one corresponding to the steroid testosterone and the other to $5 \beta$-androstane- $3 \beta, 17 \beta$ diol. The third area was found to be $5 \beta$-dihydrotestosterone. All the compounds were confirmed by acetylation and crystallization (Table 1).

\section{DISCUSSION}

The general structure of the skin of $C$. gariepinus corresponds to that of other teleost fish (Kann, 1927; Pfeiffer, 1960, 1963, 1967; Bremer, 1972; Yamazaki, 1972). The club cells are the most characteristic elements in the epithelium of fish belonging to the Ostariophysi. These club cells are known as alarm substance cells (Pfeiffer, 1967) that do not open onto the surface, but release their contents only when the skin is injured.

The results of the biochemical study have shown that in the skin of the catfish, $\Delta^{4}$ steroids are metabolized more actively than are $\Delta^{5}$ steroids. Moreover, it appears that in skin incubations, a variety of androgens can be found as water-soluble steroid glucuronides. The results of the incubations with different precursors indicate that the skin cannot be considered as a stcroidogenic organ, but that metabolism in the skin of circulating steroids cannot be excluded. A key enzyme in steroid biosynthesis is $3 \beta$-hydroxysteroid dehydrogenase. This enzyme could be demonstrated neither enzymehistochemically nor biochemically. Pregnenolone and dehydroepiandrosterone were not converted to progesterone and androstenedione, respectively. The enzymes of the $\Delta^{4}$ and $\Delta^{5}$ route, such as $17 \alpha$-hydroxylase and $C_{17-20}$-lyase, are also absent, for $17 \alpha$-hydroxyprogesterone was not converted to androstenedione. The conversion products of $17 \alpha$-hydroxyprogesterone, androstenedione, $11 \beta$ hydroxyandrostenedione, and testosterone indicate that the main metabolic enzymes present in the skin were $5 \alpha$-reductase, $5 \beta$ reductase, $3 \alpha$-HSD, 11 $\beta$-HSD, 17 $\beta$-HSD, $20 \beta-H S D$, and steroid-glucuronosyl transferase. From enzymehistochemical studies it appeared that these metabolic enzymes are localized in the epithelial cells of the skin. 11ß-Hydroxyandrostenedione was not reduced, although the enzymes $5 \alpha$ - and $5 \beta$-reductase were present. This indicates a substrate specificity of these enzymes. A functional group at the $\mathrm{C}_{11}$ position might prevent reduction. Seminal vesicles of the 
catfish incubated with $11 \beta$-hydroxyandrostenedione create the same impression. Although the reductase enzymes are highly active, from what can be concluded from androstenedione incubations, only a minor reduction of $11 \beta$-hydroxyandrostenedione could be observed (Schoonen et al., 1987a).

The presence of some of the above-mentioned metabolic enzymes, i.e., $3 \alpha$-HSD, $17 \beta$-HSD, and $5 \alpha$-reductase, was also demonstrated in the skin of $S$. gairdneri (Hay et al., 1976) and $S$. trutta lacustris (Soivio et al., 1982).

These studies did not, however, indicate the presence of $5 \beta$-reductase, $11 \beta-H S D$, and $20 \beta-H S D$, which were found to be active in the skin of African catfish. In catfish there also was a high conversion of androgens into water-soluble steroid conjugates, in particular the glucuronides of testosterone and $5 \beta$-dihydrotestosterone. The epithelial cells can be considered as the source of these steroid glucuronides, since the presence of UDPGD in these cells in combination with enzymes involved in steroid metabolism (Van den Hurk et al., 1987b). Considerable quantities of watersoluble compounds were also found in the incubations of skin of the brown trout (Soivio et al., 1982) but these compounds were not identified. By contrast, in the skin of the rainbow trout, Hay et al. (1976) found only traces of water-soluble compounds.

The bioconversion of steroids by epithelial cells in the skin may be considered as a physiological process, since the appropriate precursors such as $17 \alpha$-hydroxyprogesterone, androstenedione, and testosterone are produced in the African catfish in testes and seminal vesicles (Schoonen and Lambert, 1986a, b; Schoonen et al., $1987 \mathrm{a}, \mathrm{b})$. The presence of these steroids was also demonstrated in the blood (De Leeuw et al., 1986).

Hay et al. (1976) have suggested that the glucuronides found in the rainbow trout skin could be detoxification products. This may also be true in the case of $C$. gariepinus. However, the possibility of steroid glucuronides, formed in the skin, playing a significant role as sex pheromones cannot be ruled out. In the African catfish, steroid glucuronide fractions, obtained from seminal vesicles and ovaries, possess pheromonal functions (Lambert et al., 1986; Resink et al., 1987). Pheromonal properties of steroid glucuronides were also demonstrated in zebrafish, $B$. rerio (Van den Hurk and Lambert, 1983) and in $G$. jozo (Colombo et al., 1980).

Production of pheromones by the skin of fish has already been suggested by Todd $e t$ al. (1967). They studied the behavior of yellow bullhead, Ictalurus natalis, and demonstrated that these animals know conspecifics by their pheromones. The main source of the intraspecific chemical stimuli involved in recognition was suggested to be the mucus. Using extracts from the skin, the urophysis, and the urinary bladder, Richards (1974) could demonstrate that the channel catfish, Ictalurus nebulosus, can discriminate between two conspecifics. Although the chemical identity of the extracts is not known, these observations clearly suggest that the skin of catfish species is involved in the production of substances with pheromonal properties.

In the African catfish steroid glucuronides can act as pheromones (Lambert et al., 1986; Resink et al., 1987). The present results indicate that the skin, and in particular its epithelial cells, is capable of synthesizing steroid glucuronides. Thus, epithelial cells of the skin might be involved in the production of semiochemicals with pheromonal properties.

\section{ACKNOWLEDGMENTS}

The first author expresses his sincere thanks to the Food and Agricultural Organisation (FAO) of the United Nations, Rome, Italy, for providing the opportunity to come to the University of Utrecht, The Netherlands, and to carry out this work. Further, he is grateful to the Director, Central Marine Fisheries Re- 
search Institute, Cochin, and the Indian Council of Agricultural Research, New Delhi, for nominating him for this program. Also, the authors thank Mrs. J. C. M. Granneman for her helpful assistance and Mrs. M. van Hattum and Mrs. E. M. Greve for typing the manuscript.

\section{REFERENCES}

Bremer, H. (1972). Einige Untersuchungen zur Histochemie der sezernierenden Elementen der Teleostier-Epidermis. Acta Histochem. 43, 28-40.

Burck, H. C. (1981). "Histologische Technik, Leitfaden für die Herstellung mikroskopischer Präparate in Unterricht und Praxis." Thieme, Stuttgart/New York.

Bush, I. E. (1961). "The Chromatography of Steroids," pp. 358-371. Pergamon, New York.

Colombo, L., Colombo Belvédère, P., Marconato, A., and Bentivegna, F. (1982). Pheromones in teleost fish. In "Proceedings of the International Symposiurn on Reproductive Physiology of Fish, Wageningen, The Netherlands, 2-6 August 1982" (C. J. J. Richter and H. J. Th. Goos, Eds.), pp. 84-94. Pudoc, Wageningen.

Colombo, L., Marconato, A., Colombo Belvédère, P., and Frisco, C. (1980). Endocrinology of teleost reproduction: A testicular steroid pheromone in black goby, Gobius jozo. L. Boll. Zool. 47, 355.-364.

De Leeuw, R., Resink, J. W., Rooyakkers, E. J. M., and Goos, H. J. Th. (1985). Pimozide modulates the luteinizing hormone-releasing hormone effect on gonadotropin release in the African catfish, Clarias lazera. Gen. Comp. Endocrinol. 58, 120-- 127.

De Leeulw, R., Wurth, Y. A., Zandbergen, M. A., Peute, J., and Goos, H. J. Th. (1986). The effect of aromatizable androgens, non-aromatizable androgens and estrogens on gonadotropin release in castrated African catfish, Clarias gariepinus (Burchell). Cell Tissue Res. 243, 587-594.

Hay, J. B., Hodgins, M. B., and Roberts, R. J. (1976). Androgen metabolism in skin and skeletal muscle of the rainbow trout (Salmo gairdneri) and in accessory sexual organs of the spur dogfish (Squalus acanthias). Gen. Comp. Endocrinol. 29, $402-413$.

Kann, S. (1927). Die Histologie der Fishhaut von biologischen Gesichtspunkten betrachtet. Z. Zellforsch. 4, 483-513.

Kellog, D. A., and Glenner, G. G. (1960). Histochemical localization of human termal placental $17 \beta$ oestradiol dehydrogenases: Implication for the transhydrogenase reaction. Nature (London) 187, $763-764$.

Lambert, J. G. D., Van den Hurk, R., Schoonen, W. G. E. J., Resink, J. W., and Van Oordt,
P. G. W. J. (1986). Gonadal steroidogenesis and the possible role of steroid glucuronides as sex pheromones in two species of teleosts. Fish Physiol. Biochem. 2, 101-107.

Pfeiffer, W. (1960). Über die Schreckreaktion bei Fischen und die Herkunft des Schreckstoffes. $Z$. Vergl. Physiol. 43, 578-614.

Pfeiffer, W. (1963). Vergleichende Untersuchungen über die Schreckreaktion und den Schreckstoff der Ostariophysen. Z. Vergl. Physiol. 47, 111-147.

Pfeiffer, W. (1967). Schreckreaktion und Schreckstoffzellen bei Ostariophysi und Gonorhynchiforms. Z. Vergl. Physiol. 56, 380-396.

Pfeiffer, W. (1982). Chemical signals in communication. In "Chemoreception in Fishes" (T. J. Hara, Ed.), pp. 307-326. Elsevier, Amsterdam.

Resink, J. W., Van den Hurk, R., and Groeninx-Van Zoelen, P. F. O. (1987). The seminal vesicle as source of sex attracting substances in the African catfish, Clarias gariepinus. Aquaculture, in press.

Richards, I. S. (1974). Caudal neurosecretory system: Possible role in pheromone production. J. Exp. Zool. 187, 405-408.

Schoonen, W. G. E. J., Granneman, J. C. M., Lambert, J. G. D., Viveen, W. J. A. R., and Van Oordt, P. G. W. J. (1987a). Quantitative studies of steroid bioconversions in the seminal vesicles of spawning male African catfish, Clarias gariepinus (Burchell), under natural conditions, and of nonspawning catfish under natural and fish farm conditions. Comp. Biochem. Physiol., in press.

Schoonen, W. G. E. J., and Lambert, J. G. D. (1986a). Steroid metabolism in the testes of the African catfish, Clarias gariepinus (Burchell), during the spawning season, under natural conditions and kept in ponds. Gen. Comp. Endocrinol. 61, 40-52.

Schoonen, W. G. E. J., and Lambert, J. G. D. (1986b). Steroid metabolism in the seminal vesicles of the African catfish, Clarias gariepinus (Burchell) during the spawning season, under natural conditions and kept in ponds. Gen. Comp. Endocrinol. 61, 355-367.

Schoonen, W. G. E. J., Lambert, J. G. D., Resink, J. W., Viveen, W. J. A. R., and Van Oordt, P. G. W. J. (1987b). A quantitative study of steroid bioconversions in the testes of the African catfish, Clarias gariepinus (Burchell), under natural spawning and natural and cultivated nonspawning conditions. J. Endocrinol. 112,323-332.

Schoonen, W. G. E. J., Van Bennekum, A. M., Lambert, J. G. D., Viveen, W. J. A. R., and Van Oordt, P. G. W. J. (1987c). Steroidogenesis in pre- and postspawned ovaries of feral African 
catfish, Clarias gariepinus. Aquaculture, in press.

Soivio, A., Pesonen, S., Teravainen, T., and Nakari, T. (1982). Seasonal variations in oestrogen levels in the plasma of brown trout. (Salmo trutta la. custris) and in the metabolism of testosterone in the skin. Ann. Zool. Fennici 19, 53-59.

Todd, J. H., Atema, J., and Bardach, J. E. (1967). Chemical communication in social behavior of a fish, the yellow bull head (Ictalurus natalis). Science 158, 672-673.

Van den Hurk, R. (1973). The localization of steroidogenesis in the testes of oviparous and viviparous teleosts. Proc. Kon. Ned. Akad. Wet. Ser. C 76, 270-279.

Van den Hurk, R., and Lambert, J. G. D. (1983). Ovarian steroid glucuronides function as sex pheromones for male zebrafish, Brachydario rerio. Canad. J. Zool. 61, 2381-2387.

Van den Hurk, R., Resink, J. W., and Peute, J. (1987a). The seminal vesicle of the African catfish, Clarias gariepinus: A histological, histo- chemical, enzymehistochemical, ultrastructural and physiological study. Cell Tissue Res. 274, 573-582.

Van den Hurk, R., Resink, J. W., and Voorthuis, P. (1987b). An enzyme-histochemical study concerning the localization of steroid glucuronide production in the reproductive organs of African catfish, Clarias gariepinus. Aquaculture, in press.

Van den Hurk, R., Van Zoelen, G. A., Schoonen, W. G. E. J., Resink, J. W., Lambert, J. G. D., and Van Oordt, P. G. W. J. (1987). The testicular steroid glucuronides of zebrafish, Brachydanio rerio, evoke ovulation in female conspecifics. Gen. Comp. Endocrinol., in press (abstract).

Wright, R. S. (1971). A reagent for the non-destructive location of steroids and some other lipophilic materials on silica gel thin layer chromatograms. $J$. Chromatogr. 59, 220-221.

Yamazaki, F. (1972). Effects of methyltestosterone on the skin and the gonad of Salmonids. Gen. Comp. Endocrinol. Suppl. 3, 741-750. 